\title{
ОЦІНКА КЛІНІЧНОЇ ЕФЕКТИВНОСТІ АЛЕРГЕНІМУНОТЕРАПІЇ У ПАЦІЕНТІВ З АЛЕРГІЧНИМИ ХВОРОБАМИ
}

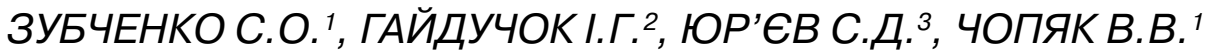 \\ 1Львівський національний медичний університет імені Данила Галицького \\ ${ }^{2}$ ТзОВ «Львівський медичний інститут» \\ ${ }^{3}$ Національний медичний університет імені О. О. Богомольця
}

Вступ. На сьогоднішній день алергію можна сміливо назвати хворобою XXI століття. 3 кожним роком збільшується кількість пацієнтів, які звертаються зі скаргами, пов'язаними з різними видами алергопатології [1, 10]. Прояви алергічних хвороб різноманітні, а, відтак, різними $€$ варіанти терапії гострих алергічних станів і хронічних алергічних захворювань. Важливо, що симптоматична фармакотерапія у більшості випадків лише тимчасово купує алергосимптоматику, а в низки пацієнтів після тривалого використання певних препаратів формується резистентність. Натомість, єдиним патогенетично обумовленим методом лікування алергічних захворювань, який був визнаний Всесвітньою організацією охорони здоров'я, є специфічна алергенімунотерапія (AIT). Специфічна AIT полягає у багаторазовому введенні сенсибілізованим особам причинно-значущих алергенів у субпорогових дозах, що призводить до активації імуномодулюючих механізмів і забезпечення стійкої ремісії симптомів під час подальшого впливу природних алергенів [2, 7]. На сьогодні AIT добре себе зарекомендувала при лікуванні алергічного риніту (AP), алергічної бронхіальної астми (БА), атопічного дерматиту (АД), інсектної алергії тощо [5, 12, 13, 17]. Традиційно AIT проводять у вигляді субкутанних ін'єкцій (CKIT). Сублінгвальний підхід (СЛІТ) як альтернатива, на сьогоднішній день набув значного інтересу і також широко використовується, особливо у дитячій популяції $[11,15]$. Звичайно, ефективність AIT залежить від якості алерговакцини, однак темою багатьох дискусій залишаються питання досконалості методик введення препарату, їх клінічної ефективності, безпеки в плані побічних реакцій $[8,13]$.

Метою нашої роботи було проаналізувати клінічну ефективність АІT з використанням різних способів введення алерговакцини (СЛІт і (KIT) у пацієнтів з алергічними хворобами.

Матеріали і методи. Дослідження проводилось відповідно до 7-го перегляду принципів Гельсінкської декларації прав людини (2013), Конвенції Ради Європи про права людини і біомедицину та відповідних законів України. У ран- домізований спосіб обстежено 858 хворих, які звернулись на консультативний прийом на кафедру клінічної імунології та алергології лнМу ім. Данила Галицького впродовж 2016-2017 років із попередньою стратифікацією за наявністю алергічної симптоматики. Всім пацієнтам проводили комплексне клініко-лабораторне обстеження, інструментальні, цитологічні та специфічні алергологічні дослідження.

Шкірні прик-тести (ШПТ) виконували екстрактами респіраторних алергенів (Inmunotek, Іспанія) за стандартною методикою [9]. Рівень загального сироваткового IgE і специфічних IgE до компонентів алергенів визначали за допомогою колориметричного ферментного аналізу (Macro Array Diagnostic) ALEX, Австрія [10]. Оцінку функції зовнішнього дихання проводили за допомогою діагностичного комплексу Спектр+ «Нейрософт», Харків (Україна). Вимірювання оксиду азоту проводили з використанням електрохімічного аналізатора NioxVero® (Circassia) [3].

Для СКIT використовували АЛКСОЇД (суміш полімеризованих екстрактів алергенів), для СЛІТ - спрей сублінгвальний ОРАЛТЕК (Суміш алергенів) і ОРАЛТЕК (Моноалерген), виробництва «Inmunotek», Іспанія.

Клінічні діагнози визначені за критеріями Allergic Rhinitis and its Impact on Asthma (ARIA, 2016), Global initiative for asthma (GINA, 20162017), уніфікованим клінічним протоколом «Атопічний дерматит» (2016).

Оцінку ефективності проводили за візуальною аналоговою шкалою (ВАШ) $[14,16]$. За допомогою лінійки оцінювання вимірювали відстані (мм) на 10-сантиметровій лінії між кінцем «відсутність ознак симптому» та міткою пацієнта, забезпечуючи діапазон оцінок від 0-100, зокрема: відсутність симптому (або ознак) (0-4 мм), легкі ознаки (ознака / симптом чітко присутні, але 3 мінімальною вираженістю; легко переноситься) (5-44 мм), помірні ознаки (певне відчуття ознаки / симптому, що турбує, але переноситься легко) (45-74 мм) та тяжкі ознаки (ознака / симптом, який тяжко переносити; порушує щоденну працездатність і життя і / або сон). (75-100 мм). 
Розподіл симптомів наступний: верхні симптоми (четверо носових і троє неносових (очних) симптомів), двоє нижніх симптомів. Порівнювали симптоми до лікування і після $6,12,24,36$ місяців AIT.

У групу для подальшого дослідження увійшло 165 осіб, з них 73 (44,2\%) жінок і 92 (55,8\%)

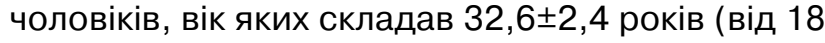
до 52 років), які дали інформовану згоду на проведення AIT і за власним бажанням визначили спосіб введення алерговакцини: група СЛІт - 87 $(52,7 \%)$ осіб і група СКIT - 78 (47,3\%) осіб. Групу порівняння склали 42 пацієнти з АХ відповідного віку і статі, які з різних причин відмовились від AIT і приймали відповідну симптоматичну терапію.

Статистичну обробку результатів досліджень здійснювали із застосуванням загальноприйнятих методів варіаційної статистики за допомогою статистичного пакету прикладних програм «Microsoft Office Excel-2011» і «Statistica for Windows» 3 використанням t-критерію Ст'юдента. Для оцінки достовірності відмінностей виборок застосовували непараметричний метод за критерієм Wilcoxona. За мінімальний поріг вірогідності приймали значення $\mathrm{p}<0,05$ [6].

Результати дослідження. На момент консультативного обстеження пацієнти звернулися 3 наступними скаргами $(n=207)$ : у 102 $(49,3 \%)$ хворих - періодичне чихання, у 92 $(44,4 \%)$ - ринорея, у $140(67,6 \%)$ - закладеність носа, у 102 (49,3\%) - свербіж, у 73 (35,3\%) ринокон'юнктивіт, у 37 (17,9\%) - сухість шкірних покривів, у 19 (9,2\%) - еритематозно-сквамозні висипання на шкірі верхніх кінцівок, верхньої частини грудної клітки, шиї тощо зі свербежем, у $51(24,6 \%)$ - кашель різного характеру, у 27 (13,0\%) - утруднене дихання.

У загальному аналізі крові у 39 (18,8\%) осіб виявлена еозинофілія легкого ступеня (від 0,6 до 1,5 Г/л). У мазку-відбитку слизової порожнини носа у 104 (50,2\%) осіб виявлена збільшена кількість еозинофілів (від 17,0\% до 65,0\% у полі зору). За даними інструментальних досліджень: ОФВ1 складав в середньому 73,2ะ2,1\%, середні результати FeNO (ppb) - 27,3 +5,4.

Усім пацієнтам проведені ШПТ екстрактами суміші різних груп респіраторних алергенів. За результатами ШПТ виявлено: у 82 хворих $(39,6 \%)$ була сенсибілізація алергенами кліщів домашнього пилу (КДП), у 102 (49,3\%) - до екстракту трав, у 55 (26,6\%) - до алергенів весняних дерев, у 14 (6,8\%) - суміші бур'янів, у 15 (7,2\%) - домашніх тварин (кіт, собака), у семи (3,4\%) - цвілевих грибків (A. Alternata). Причому, у 134 $(64,7 \%)$ пацієнтів виявлена полісенсибілізація.

Згідно Консенсусу з молекулярної алергодіагностики (A WAO-ARIA-GA2LEN consensus document on molecular-based allergy diagnostics, 2013), отримавши на перших етапах досліджень анамнестичні, клінічні дані, які вказували на наявність у всіх пацієнтів алергопатології і підтверджувались позитивними ШПТ до респіраторних алергенів, пацієнтам (особливо з полісенсибілізацією) було запропоновано виконати молекулярні дослідження [10]. У подальшому молекулярні дослідження виконали пацієнти, які вирішили приймати AIT (n=165).

На підставі аналізу молекулярних досліджень за допомогою ALEX у пацієнтів була підтверджена сенсибілізація до мажорних респіраторних алергенів, а в деяких осіб також виявлені мінорні компоненти: у чотирьох $(2,4 \%)$ - дерев (Bet v 4), у 14 (8,5\%) - злакових трав ( Phl p 7/12) і в одного $(0,6 \%)$ - КДП (Der p 10).

AIT різними способами введення рекомендували пацієнтам 3 наявністю мажорних компонентів (висока ефективність) або мажорних+мінорних компонентів (середня ефективність) [10]. Зауважимо, що серед цих пацієнтів не було осіб лише з мінорними компонентами і, відповідно - прогностично низькою ефективністю АІT.

Таким чином, використовуючи компонентну алергодіагностику на етапі виявлення справжньої сенсибілізації у пацієнтів з АР та/чи БА та/чи АД, сенсибілізованих до різних груп респіраторних алергенів, ми прогнозували ефективність AIT до її призначення: 149 (90,3\%) хворим з високим і 16 (9,7\%) особам з середнім прогнозами ефективності терапії.

Дослідження загального сироваткового IgE (за ALEX) показали, що в 102 (61,8\%) хворих виявлено збільшення вмісту цього показника у крові в межах 284 $75,4 \mathrm{MO} / \mathrm{мл}$.

На підставі суб'єктивних і об'єктивних показників, результатів лабораторних і специфічних алергологічних досліджень, за критеріями позиційних документів у пацієнтів були верифіковані різні типи алергічних хвороб і запропоновано AIT. Розподіл пацієнтів по групах залежно від верифікованого діагнозу і способу введення алерговакцини подано в таблиці 1.

Найчастіше пацієнти на СЛІт отримували Суміш алергенів трав, КДП і дерев, а четверо осіб отримували по дві вакцини (Суміші трав і КДП, суміші дерев і трав) за рекомендованою схемою: до обіду і після обіду. Аналогічно, як і у випадку приймання СЛІт, пацієнти на СКIT найчастіше отримували суміш алергенів трав, КДП і дерев; з них четверо осіб отримували по дві вакцини (суміші трав і КДП, КДП і дерев) за відповідною схемою. Пацієнти на AIT (при необхідності) і групи порівняння отримували відповідну протоколам симптоматичну і базисну терапію. 
Розподіл пацієнтів по групах залежно від верифікованого діагнозу

\begin{tabular}{|l|c|c|c|}
\hline \multicolumn{1}{|c|}{ Діагноз } & \multicolumn{1}{|c|}{$\begin{array}{c}\text { Група СлІт } \\
\text { (n=87) }\end{array}$} & $\begin{array}{c}\text { Група СКІт } \\
\text { (n=78) }\end{array}$ & $\begin{array}{c}\text { Контрольна група } \\
\text { (n=42) }\end{array}$ \\
\hline $\begin{array}{l}\text { АР інтермітуючий/ персисту- } \\
\text { ючий }\end{array}$ & $63(72,4 \%)$ & $57(73,1 \%)$ & $4(73,8 \%)$ \\
\hline $\begin{array}{l}\text { БА інтермітуюча або легка } \\
\text { персистуюча }\end{array}$ & $9(10,3 \%)$ & $8(10,3 \%)$ & $3(7,2 \%)$ \\
\hline АД дорослого типу & $6(6,9 \%)$ & $4(5,1 \%)$ & $4(9,5 \%)$ \\
\hline Коморбідна алергопатологія & $9(11,4 \%)$ & $9(11,5 \%)$ & $4 \%)$ \\
\hline
\end{tabular}

Ефективність терапії визначалася за допомогою оцінки клінічних симптомів із використанням шкали ВАШ. Зокрема, при аналізі верхніх носових симптомів нами відзначалося достовірне зниження оцінки за ВАШ при використанні СЛІТ з 34,0 мм $(24,0 ; 50,0)$ на початку лікування до 10,0 мм (6,0;16,0) через 36 місяців терапії $(p=0,0003)$. Схожа картина виявлялась і при використанні CKIT: 32,5 мм $(20,0 ; 52,3)$ до початку лікування проти 9,0 мм $(5,0 ; 15,0)$ через 36 місяців терапії, $p=0,0002$ (рис. 1).

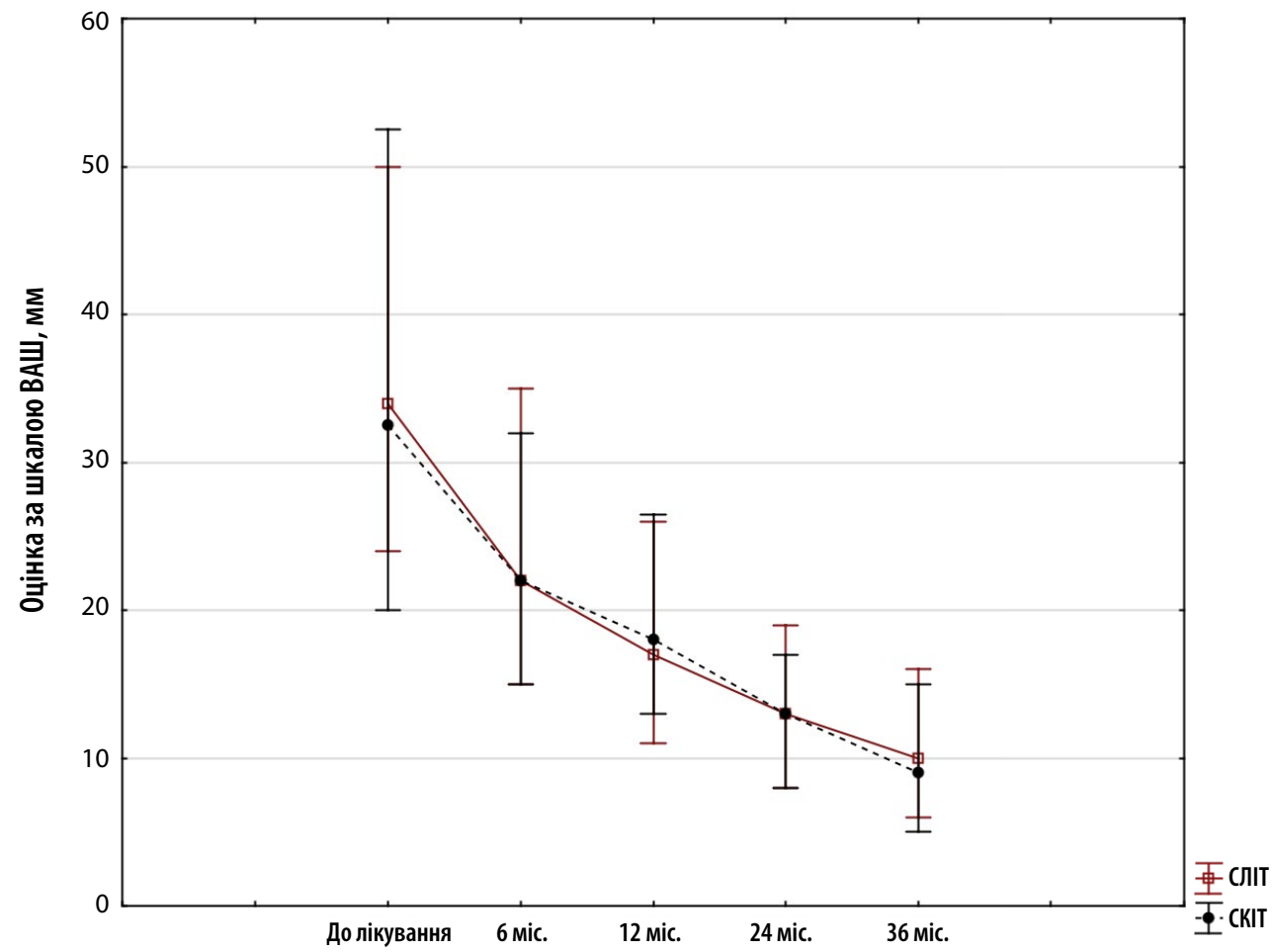

Рис. 1 Результати оцінки верхніх носових симптомів за шкалою ВАШ у пацієнтів, які отримували СЛІТ (n=87) і СКIT (n=78)

Водночас достовірної різниці щодо оцінки за ВАШ верхніх носових симптомів між групами дослідження на усіх етапах оцінювання нами не спостерігалося $(p>0,05)$.

Що стосується верхніх неносових симптомів, то на тлі проведення СЛІТ і СКIT ми також виявили достовірне їх зниження на 36 тижні спостереження порівняно з вихідним рівнем: з 35,0 мм $(25,0 ; 44,0)$ до 11,0 мм $(9,0 ; 14,0), p=0,0003$ та 334,5 мм $(25,0 ; 45,0)$ до 11,0 мм $(7,0 ; 13,0)$, $\mathrm{p}=0,0004$, відповідно (рис. 2). 


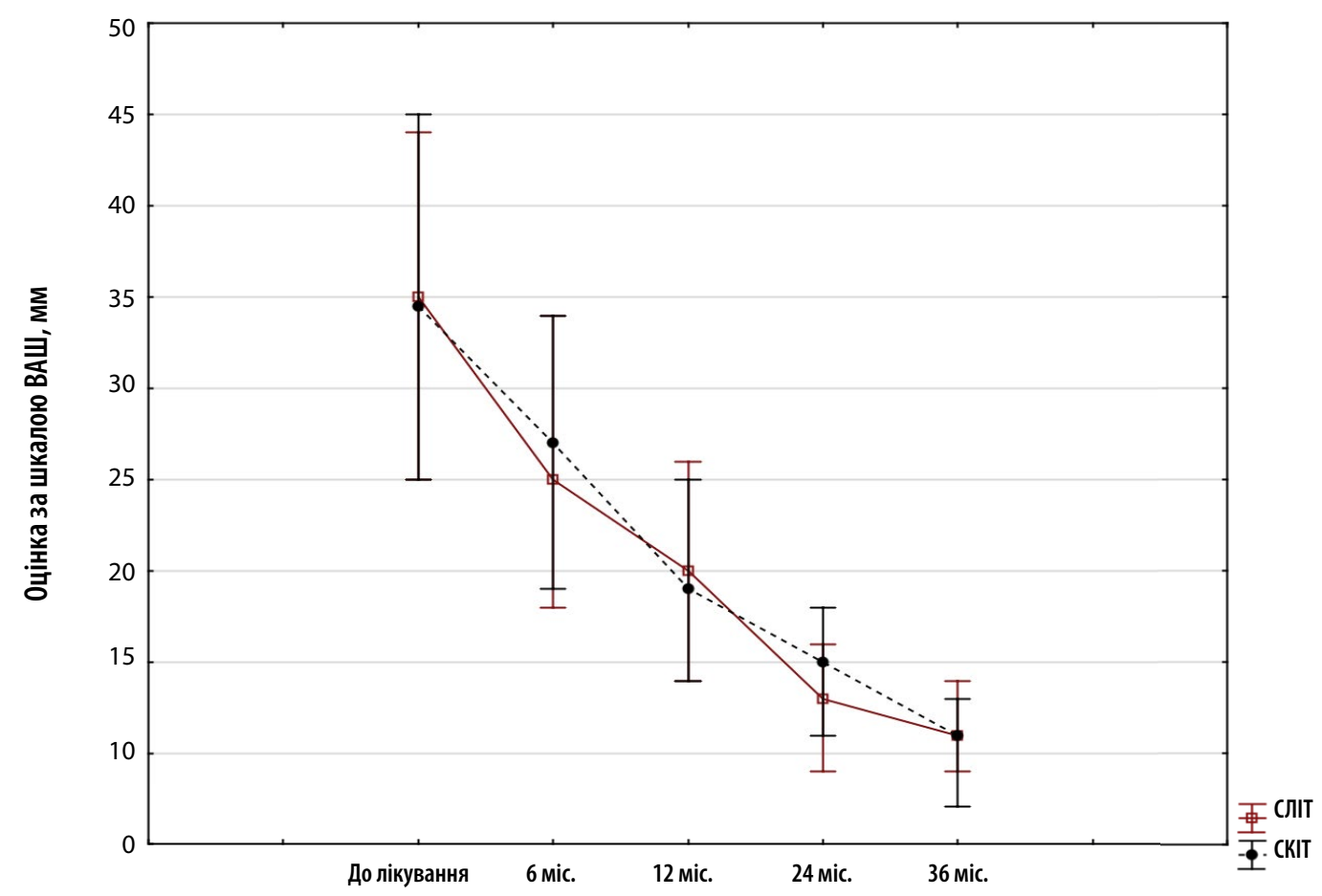

Рис. 2 Результати оцінки верхніх неносових симптомів за шкалою ВАШ у пацієнтів, які отримували СЛІТ (n=87) і СКIT (n=78)

Достовірної різниці оцінки верхніх неносових симптомів за ВАШ при проведенні СЛІТ і CKIT на усіх етапах спостереження $(p>0,05)$ не спостерігалося.

При аналізі оцінок нижніх симптомів за ВАШ, застосування СЛІТ і СКIT також характеризувалося достовірним зниженням даної алерго- сиптоматики: 3 29,5 мм (24,0;37,0) до 10,0 мм $(8,0 ; 13,0), p=0,0001$, та з 31,5 мм $(22,0 ; 37,0)$ до 10,0 мм $(8,0 ; 13,0), p=0,0001$, відповідно. Як і при верхніх симптомах, достовірної різниці у динаміці оцінки нижніх симптомів за ВАШ залежно від виду AIT не спостерігалося (рис 3).

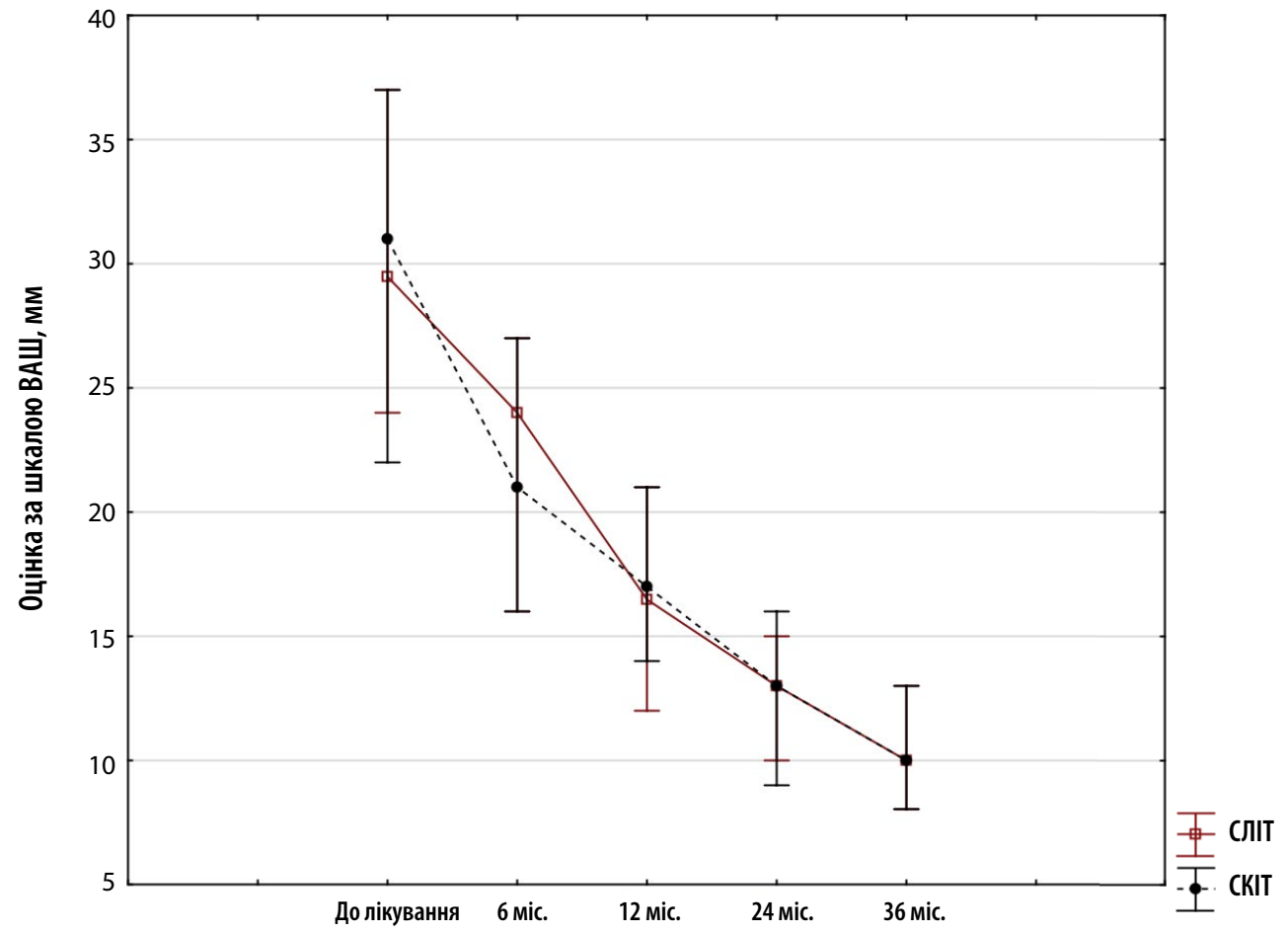

Рис. 3 Результати оцінки нижніх симптомів за шкалою ВАШ у пацієнтів, які отримували СЛІТ (n=87) і СКIT (n=78) 
Про ефективність використання АІT щодо оцінки нижніх симптомів у пацієнтів з БА свідчать і дані інструментальних досліджень (показники спірометрії і FeNO). Якщо до початку AIT середні показники ОФВ1, \% складали $75,8 \pm 4,8$ і $71,4 \pm 3,9$, то після 36 місяців $-84,7 \pm 6,3(p=0,034)$ та 83,5 $\pm 4,7$ ( $p=0,028)$ (при СЛІТ і СКІТ, відповідно). Подібна різниця була і при оцінці показни-

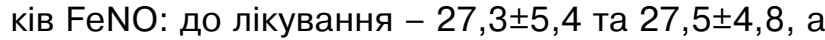
після 3-х років AIT 19,7 $\pm 6,2$ ( $p=0,034)$ і $18,9 \pm 3,3$ ( $p=0,041)$ (при СЛІТ і СКІТ, відповідно).

Зважаючи на відсутність достовірної різниці при використанні СЛІТ і CKIT, у подальшому ми об'єднали даних пацієнтів у групу АІT. Порівняння результатів лікування у групі AІT з контрольною групою наведено в таблиці 2.

Порівняння показників ВАШ на тлі проведення AIT з контрольною групою

Таблиця 2

\begin{tabular}{|c|c|c|c|c|c|c|c|c|c|c|}
\hline \multirow[b]{2}{*}{$\begin{array}{c}\text { Ознака, } \\
\text { мм } \\
(0-100)\end{array}$} & \multicolumn{5}{|c|}{ Група AIT (n=165) } & \multicolumn{5}{|c|}{ Контрольна група (n=42) } \\
\hline & $\begin{array}{c}\text { До } \\
\text { лікува- } \\
\text { ння }\end{array}$ & 6 мic. & 12 мiс. & 24 мic. & 36 мic. & $\begin{array}{c}\text { До } \\
\text { лікуван- } \\
\text { ня }\end{array}$ & 6 міс. & 12 мiс. & 24 мic. & 36 мic. \\
\hline \multicolumn{11}{|c|}{ Верхні симптоми ( ${ }^{1}$ - носові симптоми, ${ }^{2}-$ неносові симптоми) } \\
\hline Чихання ${ }^{1}$ & $\begin{array}{c}37,0 \\
(26,0 ; 48,0)\end{array}$ & $\begin{array}{c}22,0^{\wedge} \\
(16,0 ; 27,0)\end{array}$ & $\begin{array}{c}17,0^{\wedge} \\
(12,0 ; 20,0)\end{array}$ & $\begin{array}{c}11,0^{\wedge} \\
(8,0 ; 14,0)\end{array}$ & $\begin{array}{c}7,0^{\wedge} \\
(4,0 ; 9,0)\end{array}$ & $\begin{array}{c}38,0 \\
(23,5 ; 49,5)\end{array}$ & $\begin{array}{c}24,5^{\wedge}(18,3 \\
39,5)\end{array}$ & $\begin{array}{c}29,0 *(21,3 ; \\
36.8)\end{array}$ & $\begin{array}{c}33,5^{\star}(20,5 \\
45,8)\end{array}$ & $\begin{array}{c}42,0^{\star}(29,5 ; \\
55,0)\end{array}$ \\
\hline Ринорея ${ }^{1}$ & $\begin{array}{c}48,0 \\
(27,0 ; 64,0) \\
\end{array}$ & $\begin{array}{c}30,0^{\wedge} \\
(19,0 ; 38,0) \\
\end{array}$ & $\begin{array}{c}27,0^{\wedge} \\
(19,0 ; 36,0)\end{array}$ & $\begin{array}{c}19,0^{\wedge} \\
(13,0 ; 25,0) \\
\end{array}$ & $\begin{array}{c}15,0^{\wedge}(8,0 \\
21,0)\end{array}$ & $\begin{array}{c}45,5(28,0 \\
56,8) \\
\end{array}$ & $\begin{array}{c}42,0^{\star}(28,5 ; \\
48,8)\end{array}$ & $\begin{array}{c}38,0 *(31,3 ; \\
42,0)\end{array}$ & $\begin{array}{c}27,0^{\star} \\
(21,3 ; 32,0)\end{array}$ & $\begin{array}{c}28,5^{\star} \\
(25,0 ; 33,8)\end{array}$ \\
\hline $\begin{array}{c}\text { Свербіж } \\
\text { носа }^{1}\end{array}$ & $\begin{array}{c}16,0 \\
(9,0 ; 24,0)\end{array}$ & $\begin{array}{c}13,0(7,0 ; \\
18,0)\end{array}$ & $\begin{array}{c}11,0^{\wedge}(6,0 \\
15,0)\end{array}$ & $\begin{array}{c}10,0^{\wedge}(6,0 \\
14,0)\end{array}$ & $\begin{array}{c}7,0^{\wedge}(4,0 \\
12,0)\end{array}$ & $\begin{array}{c}19,5(12,0 ; \\
26,8)\end{array}$ & $\begin{array}{c}12,0^{\wedge}(8,0 ; \\
17,0)\end{array}$ & $\begin{array}{l}10,0 \\
(7,0 ; \\
17,0)\end{array}$ & $\begin{array}{c}10,0(7,0 \\
14,8)\end{array}$ & $\begin{array}{c}12,0^{\star \wedge} \\
(6,3 ; 16,8)\end{array}$ \\
\hline $\begin{array}{c}\text { Закладе- } \\
\text { ність } \\
\text { носа }^{1}\end{array}$ & $\begin{array}{c}44,0 \\
(32,0 ; 58,0)\end{array}$ & $\begin{array}{c}34,0^{\wedge}(22,0 \\
44,0)\end{array}$ & $\begin{array}{c}26,0^{\wedge}(17,0 ; \\
35,0)\end{array}$ & $\begin{array}{c}17,0^{\wedge}(10,0 ; \\
24,0)\end{array}$ & $\begin{array}{c}14,0^{\wedge}(8,0 \\
21,0)\end{array}$ & $\begin{array}{c}39,5(22,5 ; \\
46,8)\end{array}$ & $\begin{array}{c}37,0(21,0 \\
57,3)\end{array}$ & $\begin{array}{r}28 \\
(22,3\end{array}$ & $\begin{array}{r}26 \\
(18,8\end{array}$ & $\begin{array}{r}24 \\
(21,0 ;\end{array}$ \\
\hline $\begin{array}{c}\text { Свербіж } \\
\text { очей }^{2}\end{array}$ & $\begin{array}{c}25,0 \\
(20,0 ; 33,0)\end{array}$ & $\begin{array}{c}20,0^{\wedge}(15,0 ; \\
27,0)\end{array}$ & $\begin{array}{c}17,0^{\wedge}(12,0 ; \\
26,0)\end{array}$ & $\begin{array}{c}13,0^{\wedge}(10,0 ; \\
16,0)\end{array}$ & $\begin{array}{c}14,0^{\wedge}(11,0 \\
17,0)\end{array}$ & $\begin{array}{c}24,5(19,0 \\
29,0)\end{array}$ & $\begin{array}{c}16,5^{\wedge}(13,3 \\
20,0)\end{array}$ & $\begin{array}{r}26,0^{*}( \\
29,\end{array}$ & $\begin{array}{c}18,5^{\star}(14,0 ; \\
26,0)\end{array}$ & $\begin{array}{r}21 \\
(16,3 ;\end{array}$ \\
\hline $\begin{array}{c}\text { Почерво- } \\
\text { ніння } \\
\text { очей }^{2}\end{array}$ & $\begin{array}{c}40,0 \\
(30,0 ; 48,0)\end{array}$ & $\begin{array}{c}31,0^{\wedge}(23,0 ; \\
37,0)\end{array}$ & $\begin{array}{c}21,0^{\wedge}(15,0 ; \\
26,0)\end{array}$ & $\begin{array}{c}14,0^{\wedge}(10,0 ; \\
17,0)\end{array}$ & $\begin{array}{c}9,0^{\wedge} \\
(7,0 ; 12,0)\end{array}$ & $\begin{array}{c}46,0(32,3 ; \\
57,0)\end{array}$ & $\begin{array}{c}30,0^{\wedge}(23,0 \\
35,0)\end{array}$ & $\begin{array}{c}33,0^{\star} \\
(25,3,0 ; \\
37,8)\end{array}$ & $\begin{array}{c}29,0^{\star}(24,3 \\
36,8)\end{array}$ & $\begin{array}{c}38,0^{\star} \\
(30,3 ; 43,5)\end{array}$ \\
\hline $\begin{array}{c}\text { Виділен- } \\
\text { ня } 3 \\
\text { очей }^{2} \\
\end{array}$ & $\begin{array}{c}40,0 \\
(30,0 ; 52,0)\end{array}$ & $\begin{array}{c}28,0^{\wedge}(21,0 ; \\
37,0)\end{array}$ & $\begin{array}{c}19,0^{\wedge}(14,0 ; \\
24,0)\end{array}$ & $\begin{array}{c}15,0^{\wedge}(12,0 ; \\
18,0)\end{array}$ & $\begin{array}{c}10,0^{\wedge} \\
(7,0 ; 12,0)\end{array}$ & $\begin{array}{c}40,5(30,3 \\
48,8)\end{array}$ & $\begin{array}{c}26,0^{\wedge}(21,0 \\
35,0)\end{array}$ & $\begin{array}{c}28,5^{\star}(25,0 \\
35,0)\end{array}$ & $\begin{array}{c}30,0^{\star}(24,3 \\
35,8)\end{array}$ & $\begin{array}{c}31,5^{\star} \\
(32,43 ; \\
35,8)\end{array}$ \\
\hline \multicolumn{11}{|c|}{ Нижні симптоми (симптоми астми) } \\
\hline $\begin{array}{c}\text { Утруд- } \\
\text { нене } \\
\text { дихання }\end{array}$ & $\begin{array}{c}33,0 \\
(25,0 ; 34,0)\end{array}$ & $\begin{array}{c}25,0^{\wedge}(20,0 ; \\
31,0)\end{array}$ & $\begin{array}{c}20,0^{\wedge}(16,0 ; \\
24,0)\end{array}$ & $\begin{array}{c}13,0^{\wedge}(10,0 \\
15,0)\end{array}$ & $\begin{array}{c}10,0^{\wedge} \\
(9,0 ; 12,0)\end{array}$ & $\begin{array}{c}36,5(29,5 \\
42,8)\end{array}$ & $\begin{array}{c}24,0^{\wedge}(18,3 \\
34,0)\end{array}$ & $\begin{array}{c}25,0^{\star}(20,0 \\
32,0)\end{array}$ & $\begin{array}{c}28,0^{\star}(23,0 \\
33,0)\end{array}$ & $\begin{array}{c}27,0^{\star} \\
(23,0 ; 32,8)\end{array}$ \\
\hline Кашель & $\begin{array}{c}28,0 \\
(21,0 ; 35,0)\end{array}$ & $\begin{array}{c}19,0^{\wedge}(14,0 \\
25,0)\end{array}$ & $\begin{array}{c}14,0^{\wedge}(11,0 ; \\
18,0)\end{array}$ & $\begin{array}{c}13,0^{\wedge}(8,0 \\
16,0)\end{array}$ & $\begin{array}{c}11,0^{\wedge}(7,0 \\
13,0)\end{array}$ & $\begin{array}{c}29,0(22,0 ; \\
33,0)\end{array}$ & $\begin{array}{c}19,0^{\wedge}(16,0 \\
22,0)\end{array}$ & $\begin{array}{c}22,5^{\star}(17,3 ; \\
28,8)\end{array}$ & $\begin{array}{c}23,0^{\star}(17,3 \\
25,0)\end{array}$ & $\begin{array}{c}21,5^{\star} \\
(18,0 ; 25,8)\end{array}$ \\
\hline
\end{tabular}

Примітки: - p<0,05 - між групами дослідження на кожному з етапів спостереження;

$\wedge$ - $p<0,05-$ порівняно з вихідними значеннями

Загалом, ми не спостерігали достовірної різниці щодо оцінки верхніх носових симптомів за ВАШ при проведенні АІT і базової терапії на 6 місяці лікування $(22,0$ мм $(15,0 ; 23,0)$ проти 25,0 мм $(16,8 ; 42,3), p=0,091)$. Водночас, уже починаючи з 12 місяця лікування $(18,0$ мм $(12,0 ; 26,0)$ проти 26,0 мм $(17,0 ; 37,0), p=0,021)$, на 24 місяці $(13,0$ мм $(8,0 ; 19,0)$ проти 23,0 мм $(14,8 ; 34,0)$, $\mathrm{p}=0,009)$ та на 36 місяці спостереження $(9,0 \mathrm{mM}$ $(5,0 ; 15,0)$ проти 25,5 мм $(17,8 ; 37,0), p=0,001)$, статистична різниця щодо оцінки за шкалою ВАШ між групами дослідження виявлялась достовірною.

На підставі виконаних досліджень можна зробити наступний висновок: проведений трьохрічний курс AIT вакциною виробництва «Inmunotek», Іспанія, незалежно від способів іï введення (сублінгвального чи підшкірного), продемонстрував точність персоніфікованого вибору алерговакцини на підставі молекулярних досліджень і високу клінічну ефективність у пацієнтів з різними типами AX, що підтверджувалось критеріями ВАШ.

\section{ЛITEPATУРA}

1. Аллахвердиева Л.И., Салим-заде Г.Э. Алгоритм отбора пациентов и мониторинг эффективности аллерген-специфической иммунотерапии. Journal of Azerbaijan Allergy and Clinical Immunology, Scientific-practical journal Vol. 5; № 2, 2017, P43-52.

2. Воробьева О.В., Гущин И.С. Молекулярнобиологические основы аллерген-специфической иммунотерапии. Вестник биотехнологии и физико-химической биологии им. Ю.А. Овчинникова. 2011;7(3):54-71.

3. Гашинова К.Ю. Вимірювання фракції видихуваного оксиду азоту (FeNO) при астмі: космічні технології в реальній клінічній 
практиці. Клінічна імунологія. Алергологія. Інфектологія. 2020;2(123):66-38.

4. Зубченко С.О., Маруняк С.P. Оцінювання якості життя пацієнтів із пилковою алергією до та після курсу сублінгвальної імунотерапії. Патологія. 2018;2(43):201-215.

5. Маслова Л.В. Сублингвальная иммунотерапия респираторной аллергии: иммунологическая эффективность. Імунологія та алергологія: наука і практика, №2 (2013), C.2-11.

6. Реброва О. Ю. Статистический анализ медицинских даных. Приминение пакета прикладных програм STATISTICA. М:Медиасфера; 2002. 312 c.

7. Akdis M., Akdis C.A. Mechanisms of allergen-specific immunotherapy. J. Allergy Clin. Immunol. 2007;119(4):780-789.

8. Bae J.M., Choi Y.Y., Park C.O., Chung K.Y., Lee K.H. Efficacy of allergen-specific immunotherapy for atopic dermatitis: a systematic review and meta-analysis of randomized controlled trials. J. Allergy Clin. Immunol. 2013;132(1):110-117.

9. Bousquet J, Heinzerling $L$, Bachert $C$, Papadopoulos N, Bousquet P, Burney $P$ et al. Practical guide to skin prick tests in allergy to aeroallergens. Allergy. 2012 Jan;67(1):18-24.

10. Canonica G.W, Ansotequi I.J., Pawankar R., Schmid-Grendelmeier P., Marianne van Hage, Baena-Cagnani C. et al. A WAO-ARIA-GA2LEN consensus document on molecular-based allerdy diagnostics. World Allergy Organ. J 2013;6:13.

11. Canonica G. W., Linda Cox, Ruby Pawankar, Carlos E Baena-Cagnani, Michael Blaiss, Sergio Bonini et al. Sublingual immunotherapy: World Allergy Organization position paper 2013 update. World Allergy Organ J. 2014 Mar 28;7(1):6. doi: 10.1186/1939-4551-7-6.

12. Choi J.S., Ryu H.R., Yoon C.H., Kim J.H., Baek J.O., Roh J.Y. et al. Treatment of patients with refractory atopic dermatitis sensitized to house dust mites by using sublingual allergen immunotherapy. Ann. Dermatol. 2015;27(1):82-86.

13. James T.L., Nelson N., Lockey R., Cox L. et al., Mechanisms of immunotherapy In: Allergen immunotherapy: A practical parameter second update. J. Allergy Clin. Immunol. 2007;120(3):38.

14. Ludger Klimek, Karl-Christian Bergmann, Tilo Biedermann, Jean Bousquet, Peter Hellings, Kirsten Jung et al. Visual analogue scales (VAS): Measuring instruments for the documentation of symptoms and therapy monitoring in cases of allergic rhinitis in everyday health care. Allergo J Int. 2017;26(1):16-24. doi: 10.1007/ s40629-016-0006-7
15. Novak N., Bieber T., Allam J.P. Immunological mechanisms of sublingual allergen-specific immunotherapy. Allergy. 2011;65(6):733-739.

16. Paul-Dauphin A, Guillemin F, Virion JM, Brian on S. Bias. Precision in Visual Analogue Scales: A Randomized Controlled Trial. American Journal of Epidemiology 1999;150(10):1117-1127 DOI: 10.1093/oxfordjournals.aje.a009937

17. Zubchenko SO, Yurjev SD, Marunyak SR. Molecular allergodiagnostics as a method of differential approach to the choice of allergoimmunotherapy for allergy to pets. Science and Education a new Dimension Natural and Technical Sciences. 2016; 4(10- Iss 91):21-29.

\section{PEЗ ЮME}

\section{ОЦІНКА КЛІНІЧНОЇ ЕФЕКТИВНОСТІ АЛЕРГЕНІМУНОТЕРАПIÏ У ПАЦІЄНТІВ З АЛЕРГІЧНИМИ ХВОРОБАМИ}

Зубченко C.O. ${ }^{1}$, Гайдучок I.Г. ${ }^{2}$, Юр'єв С.Д. ${ }^{3}$, Чопяк В.В. ${ }^{1}$

1 Львівський національний медичний університет імені Данила Галицького

${ }^{2}$ ТзОВ «Львівський медичний інститут»

${ }^{3}$ Національний медичний університет імені О. О. Богомольця

Патогенетично обумовленим методом лікування алергічних захворювань $€$ специфічна алергенімунотерапія (AIT). Існують різні способи введення алерговакцини: від традиційних - субкутанних (CKIT), до порівняно нових - сублінгвальних (СЛІТ). Ефективність алергенімунотерапії і безпека для пацієнта $€$ метою багатьох досліджень.

Мета. Аналіз клінічної ефективності АІT з використанням різних способів введення алерговакцини (СЛIT і CKIT) у пацієнтів з алергічними хворобами.

Матеріали і методи. Групу спостереження склали 165 хворих на різні алергічні хвороби, з них 73 $(44,2 \%)$ жінок і 92 (55,8\%) чоловіків, віком 32,6 22,4 років. Виконували загальні клінічні, лабораторні, інструментальні, специфічні алергологічні, в т.ч. молекулярні дослідження. Для АІТ використовували АЛКСОїД (суміш полімеризованих екстрактів алергенів), для СЛІТ - спрей сублінгвальний ОРАЛТЕК, виробництва «Inmunotek», Іспанія. Оцінку клінічної ефективності на різних етапах трьохрічного періоду лікування проводили за візуальною аналоговою шкалою (ВАШ).

Результати дослідження. Оцінку проводили у трьох групах: 87 (52,7\%) осіб (група СлІт), 78 (47,3\%) осіб (група СКIT) і 42 пацієнтів з алергічними хворобами (контрольна група). Визначили, що у пацієнтів на AIT незалежно від способу введення алерговакцини спостерігалось достовірне зниження оцінки за ВАШ верхніх носових, верхніх неносових і нижніх симптомів через 36 місяців терапії порівняно з контрольною групою. Натомість, достовірної різниці оцінки симптомів між групами на СЛIT і CKIT на усіх етапах спостереження $(p>0,05)$ не виявлено.

Висновок. Проведений трьохрічний курс АIT вакциною виробництва «Inmunotek», Іспанія, незалежно від способів ї̈ введення (сублінгвального чи субкутанного), продемонстрував точність персоніфікова- 
ного вибору алерговакцини на підставі молекулярних досліджень і високу клінічну ефективність у пацієнтів з різними типами алергічних хвороб, що підтверджувалось критеріями ВАШ.

Ключові слова: алергенімунотерапія, СКIT, СЛІТ, ВАШ, молекулярна діагностика.

\section{PЕЗЮME}

\section{ОЦЕНКА КЛИНИЧЕСКОЙ ЭФФЕКТИВНОСТИ АЛЕРГЕНИММУНОТЕРАПИИ У ПАЦИЕНТОВ С АЛЛЕРГИЧЕСКИМИ БОЛЕЗНЯМИ}

\author{
Зубченко С.О. ${ }^{1}$, Гайдучок И.Г. ${ }^{2}$, Юрьев С.Д. ${ }^{3}$, Чопяк В.В. ${ }^{1}$ \\ ${ }^{1}$ Львовский национальный медицинский университет \\ имени Данила Галицкого \\ ${ }^{2}$ ОгОО «Львовский медицинский институт» \\ ${ }^{3}$ Национальный медицинский университет \\ имени А. А. Богомольца
}

Патогенетически обусловленным методом лечения аллергических заболеваний является специфическая аллергениммунотерапия (АИТ). Существуют различные способы введения аллерговакцины: от традиционных - субкутанних (СКИТ), до сравнительно новых - сублингвальных (СЛИТ). Эффективность аллергениммунотерапии и безопасность для пациента является целью многих исследований.

Цель. Анализ клинической эффективности АИТ с использованием различных способов введения аллерговакцины (СДИТ и СКИТ) у пациентов с аллергическими болезнями.

Материалы и методы. Группу наблюдения составили 165 больных различными аллергическими болезнями, из них 73 (44,2\%) женщин и 92 (55,8\%) мужчин в возрасте $32,6 \pm 2,4$ лет. Выполняли общие клинические, лабораторные, инструментальные, специальные аллергологические, в т.ч. молекулярные исследования. Для АИТ использовали АЛКСОИД (смесь полимеризированных экстрактов аллергенов), для СЛИТ - спрей сублингвальный ОРАЛТЕК, производства «Inmunotek», Испания. Оценку клинической эффективности на разных этапах трехлетнего периода лечения проводили, используя визуальную аналоговую шкалу (ВАШ).

Результаты исследования. Оценку проводили в трех группах: 87 (52,7\%) человек (группа СлИТ), 78 $(47,3 \%)$ человек (группа СКИТ) и 42 пациента с аллергическими болезнями (контрольная группа). Определили, что у пациентов на АИТ, независимо от способа введения аллерговакцины, наблюдалось достоверное снижение оценки по ВАШ верхних носовых, верхних неносових и нижних симптомов через 36 месяцев терапии по сравнению с контрольной группой. Причём, достоверной разницы оценки симптомов между группами на СЛИТ и СКИТ на всех этапах наблюдения (р>0,05) не отмечалось.

Выводы. Проведенный трехлетний курс АИТ вакциной производства «Inmunotek», Испания, независимо от способов ее введения (сублингвального или субкутанного), продемонстрировал точность персонифицированного выбора аллерговакцины на основании молекулярных исследований и высокую клиническую эффективность у пациентов с различными типами аллергических болезней, что подтверждалось критериям ВАШ.

Ключевые слова: аллергениммунотерапия, СКИТ, СЛИТ, ВАШ, молекулярная диагностика.

\section{SUMMARY \\ EVALUATION OF CLINICAL EFFICIENCY OF ALLERGEN IMUNOTHERAPY IN PATIENTS WITH ALLERGIC DISEASES \\ Zubchenko S. ${ }^{1}$, Gaiduchok I. ${ }^{2}$, Yuriev S. ${ }^{3}$, Chopyak V. ${ }^{1}$ \\ ${ }^{1}$ Danylo Halytsky Lviv national medical university 2LLC "Lviv Medical Institute" \\ ${ }^{3}$ Bogomolets National Medical University}

Pathogenetically determined method of treatment of allergic diseases is specific allergen immunotherapy (AIT). There are different ways to administer the allergy vaccine: from traditional - subcutaneous (SKIT), to relatively new -sublingual (SLIT). The effectiveness of allergen immunotherapy and safety for each patient has been linked to many studies.

Purpose. Analysis of the clinical effectiveness of AIT using different methods of allergy vaccine (SLIT and SKIT) in patients with allergic diseases.

Materials and methods. The observation group consisted of 165 patients with various allergic diseases, including $73(44.2 \%)$ female and 92 (55.8\%) male, aged $32.6 \pm 2.4$ years. Performed general clinical, laboratory, instrumental, specific allergology, including component research. For AIT used ALXOID (a mixture of polymerized allergen extracts), for SLIT - sublingual spray ORALTEK, manufactured by Inmunotek, Spain. Evaluation of clinical efficacy at different stages of the three-year treatment period was performed on a visual analog scale (VAS).

Results. The assessment was performed in three groups: 87 (52.7\%) individuals (SLIT group), 78 (47.3\%) individuals (SKIT group) and 42 patients with allergic diseases (control group). It was determined that in patients with AIT, regardless of the method of administration of allergy vaccine, there was a significant decrease in the assessment of VAS upper nasal, upper non-nasal and lower symptoms after 36 months of therapy compared with the control group. In contrast, no significant difference in symptom assessment between the SLIT and SKIT groups was found at all stages of follow-up ( $p>0.05)$.

Conclusions. A three-year course of AIT vaccine manufactured by Inmunotek, Spain, regardless of the route of administration (sublingual or subcutaneous), demonstrated the accuracy of personalized allergy vaccine selection based on molecular studies and high clinical efficacy in patients with different types of allergic diseases, as confirmed by VAS.

Key words: allergen immunotherapy, SKIT, SLIT, VAS, component-resolved diagnostics. 


\section{АВТОРСЬКА ДОВІДКА}

\section{- Зубченко Світлана \\ Олександрівна}

к.м.н, доцент кафедри клінічної імунології та алергології Львівського національного медичного університету імені Данила Галицького

Адреса: вул. Пекарська, 69, Львів, Львівська область, 79010, Україна Моб. тел.: +38 0676706643

E-mail: svitlana zu@meta.ua http://orcid.org/0000-0003-4471-4884

\section{- Гайдучок Ігор Григорович} к.м.н, доцент, генеральний директор ТзОВ «Львівський медичний інститут» Адреса: вул. Валер'яна Поліщука, 76, Львів, Львівська область, 79018, Україна Тел.: (032) 239-37-01

E-mail: lvivmedinst@gmail.com E-mail: ihor.hayduchok@gmail.com https://orcid.org/0000-0003-2897-8417

\section{- Юр'єв Сергій Дмитрович} асистент кафедри клінічної імунології та алергології 3 курсом медичної генетики НМУ ім 0.0. Богомольця Адреса: Київ-80, вул. Турівська, 26 Моб. тел.: +38066 3966565 E-mail: s.yuriev@gmail.com https://orcid.org/0000-0003-4323-7967.

\section{- Чопяк Валентина Володимирівна \\ д.мед.н., професор кафедри клінічної імунології та алергології Львівського на- ціонального медичного університету імені Данила Галицького Адреса: вул. Пекарська, 69, Львів, Львівська область, 79010, Україна Моб. тел..: +38067 2801043 E-mail: chopyakv@ukr.net http://orcid.org/0000-0003-3127-2028}

\author{
- Зубченко Светлана \\ Александровна \\ к.м.н., доцент кафедры клинической \\ иммунологии и аллергологии Львовского \\ национального медицинского университета \\ имени Даниила Галицкого \\ Адрес: ул. Пекраская, 69, Львов, \\ Львовская область, 79010, Украина \\ Моб. тел.: +38 0676706643 \\ E-mail: svitlana zu@meta.ua \\ http://orcid.org/0000-0003-4471-4884
}

- Гайдучок Игорь Григорьевич к.м.Н., доцент, генеральный директор ОгОО «Львовский медицинский институт» Адрес: ул. Валерьяна Полищука, 76, Львов, Львовская область, 79018, Украина

Тел .: (032) 239-37-01

E-mail: Ivivmedinst@gmail.com E-mail: ihor.hayduchok@gmail.com https://orcid.org/0000-0003-2897-8417

\section{- Юрьев Сергей Дмитриевич} ассистент кафедры клинической иммунологии и аллергологии с курсом медицинской генетики НМУ им А.А. Богомольца Адрес: Киев-80, ул. Туровская, 26 Моб. тел.: +38 0663966565 E-mail: s.yuriev@gmail.com https://orcid.org/0000-0003-4323-7967.

\section{- Чопяк Валентина Владимировна}

д.мед. наук, профессор кафедры клинической иммунологии и аллергологии Львовского национального медицинского университета имени Даниила Галицкого Адрес: ул. Пекраская, 69, Львов, Львовская область, 79010, Украина Моб. тел..: +38067 2801043 E-mail: chopyakv@ukr.net http://orcid.org/0000-0003-3127-2028

\section{- Zubchenko Svitlana, PhD}

Associate Professor, Department of Clinical Immunology and Allergology, Danylo Halytsky Lviv National Medical University Address: st. Pekarska, 69, Lviv, Lviv region, 79010, Ukraine Tel.: +38 0676706643

E-mail: svitlana zu@meta.ua http://orcid.org/0000-0003-4471-4884

\section{- Gaiduchok Igor} candidate of Medical Sciences, Associate Professor, General director of LLC «Lviv Medical Institute»

Address: st. Valerian Polishchuk, 76, Lviv, Lviv region, 79018, Ukraine

Tel .: (032) 239-37-01

E-mail: lvivmedinst@gmail.com E-mail: ihor.hayduchok@gmail.com https://orcid.org/0000-0003-2897-8417

\section{- Serhii Yuriev}

Assistant of the Department of Clinical Immunology and Allergology with the course of medical genetics of the National Medical University named after 0 . Bogomolets Address: Kyiv-80, st. Turovska, 26, Ukraine Tel.: +38066 3966565

E-mail: s.yuriev@gmail.com https://orcid.org/0000-0003-4323-7967

\section{- Chopyak Valentina}

MD of Sciences, Professor, Department of Clinical Immunology and Allergology, Danylo Halytsky Lviv National Medical University

Address: st. Pekarska, 69, Lviv, Lviv region, 79010, Ukraine Tel.: +380672801043 E-mail: chopyakv@ukr.net http://orcid.org/0000-0003-3127-2028 